\title{
Upaya meminimalisasi kecemasan siswa saat berbicara di depan umum dengan metode expressive writing therapy
}

\author{
BalawanAliman Amali ${ }^{*}$, Laili Etika Rahmawati ${ }^{2}$ \\ Fakultas Keguruan Dan Imu Pendidikan, Program Studi Pendidikan Bahasa Dan Sastra Indonesia, \\ Universitas Muhammadiyah Surakarta
}

\begin{tabular}{l}
\hline Info Artikel \\
\hline Sejarah Artikel: \\
Diterima \\
26 Mei 2020 \\
Direview \\
15 September 2020 \\
Disetujui \\
28 September 2020 \\
Dipublikasikan \\
28 September 2020 \\
\hline Keywords: anxiety, expressive \\
writing therapy, public speaking.
\end{tabular}

Abstrak
Objektif: Expressive writing therapy adalah terapi yang menggunakan
aktivitas menulis sebagai sarana untuk merefleksikan pikiran dan perasaan
terdalam terhadap peristiwa yang dapat menimbulkan trauma. Pada
penelitian ini expressive writing therapy dilakukan secara berkelompok dan
merupakan terapi utama untuk membantu subjek mengembangkan mental
yang lebih kuat tentang diri dan situasi di depan umum. Penelitian ini
bertujuan untuk mengetahui tingkat kecemasan siswa saat berbicara di
depan umum dan mengetahui upaya meminimalisasi kecemasan saat
berbicara di depan umum.

Metode: Penelitian ini merupakan jenis penelitian tindakan kelas dengan instrumen pengambilan data menggunakan angket. Analisa menggunakan editing dan scoring. Jumlah subjek dalam penelitian ini berjumlah 32 orang.

Temuan: Dengan menggunakan expressive writing therapy terlihat perbedaan yang signifikan antara tingkat kecemasan saat berbicara di depan umum sebelum expressive writing therapy dan sesudahnya.

Kesimpulan: Expressive writing therapy efektif untuk siswa, karena memiliki keunggulan untuk mengatasi kecemasan berbicara di depan umum.

\section{Efforts to minimize student anxiety when speaking in public with the expressive writing therapy \\ Objectives: Expressive writing therapy is therapy that uses writing activities as a means to reflect the innermost thoughts and feelings of events that can cause trauma. In this research expressive writing therapy is done in groups and is the main therapy to help subjects develop a stronger mental about themselves and situations in public. This study aims to describe the level of student anxiety when speaking in public and describe efforts to minimize anxiety when speaking in public.}

Method: This research is a type of classroom action research with data collection instrument using a questionnaire. Analysis using editing and scoring. The number of subjects in this study amounted to 32 people.

Findings: By using expressive writing therapy there is a significant comparison between the level of anxiety when speaking in public before expressive writing therapy and after expressive writing therapy.

Conclusions: The results of expressive writing therapy test are effective for students, because they have the advantage of public speaking anxiety.

Jalan A. Yani Tromol Pos I Pabelan Kartasura, Surakarta 57I02, Indonesia

E-mail': balawanaa@gmail.com 


\section{Pendahuluan}

Salah satu kompetensi yang harus dimiliki oleh siswa yaitu berbicara di depan umum, kemampuan berbicara di depan umum tersebutlah sangat penting bagi siswa agar dapat melakukan kegiatan atau aktivitas di sekolah seperti kegiatan organisasi (OSIS), presentasi di depan kelas, serta berpidato. Dalam proses belajar berbicara di depan umum, siswa dapat melakukan kegiatan berkomunikasi secara berkelompok, dua orang atau lebih dengan berlatih presentasi, saling bertanya dan menjawab, memberi dan menerima tanggapan. Berbicara di depan umum merupakan komunikasi yang dilakukan oleh seorang kepada sejumlah orang yang berbeda latar belakang kebudayaan dalam situasi pertemuan (rapat, seminar, lokarya, simposium, dan kongres). lokarya, simposium, dan kongres). Kemampuan berbicara di depan umum sangat erat kaitannya dengan kepercayaan diri siswa. Kurangnya kepercayaan diri dalam berbicara dalam realitasnya merupakan suatu bentuk perilaku yang normal dan bukan menjadi persoalan yang serius sepanjang individu tersebut mampu mereduksi kecemasan, sehingga tingkat kecemasannya tidak berpengaruh terhadap tindak komunikasi yang dilakukannya. Kecemasan berbicara di depan umum tergolong pada kriteria fobia sosial maupun gangguan kecemasan sosial. Reaksi fisik fisiologi seperti jemari menjadi dingin, jantung berdebar kencang, keringat dingin, pening, nafas tidak teratur atau bahkan sesak nafas, sementara reasksi psikologis seperti ketakutan, susah berkonsentrasi, pesimis, dan gelisah. Kondisi tersebut ditandai dengan ketakutan dalam menunjukkan situasi. Kesetaraan gender menekankan pada kesetaraan status dan nilai pada laki-laki dan perempuan (Cahyawan \& Machdum, 2019)

Menurut Atkinson dalam (Muslimin, 2013), kecemasan merupakan emosi yang tidak menyenangkan yang ditandai dengan istilah "kekhawatiran". Situasi yang biasanya menyebabkan terjadinya kecemasan atau biasa kita menyebutnya gak kuat mental, deg-degan, gerogi, dll pada konteks berbicara di depan umum. Menurut DeVito dalam (Saputri \& Indrawati, 20I7) juga berpendapat bahwa kecemasan berbicara di depan umum merupakan bentuk dari hambatan berkomunikasi (communication apprehension) yang bisa dialami setiap individu. Kecemasan berbicara di depan umum tergolong pada kriteria fobia sosial maupun gangguan kecemasan sosial. Menurut Daradjat dalam (Bukhori, 2016) reaksi fisik fisiologi seperti jemari menjadi dingin, jantung berdebar kencang, keringat dingin, pening, nafas tidak teratur atau bahkan sesak nafas, sementara reasksi psikologis seperti ketakutan, susah berkonsentrasi, pesimis, dan gelisah. Kondisi tersebut ditandai dengan ketakutan dalam menunjukkan situasi interaksionalnya dengan orang lain. Kondisi tersebut berimplikasi terhadap kualiatas seseorang, memengaruhi fungsi sosial dan relasi dengan komunitasnya. Nevid, dkk dalam (Djayanti \& Rahmatika, 2015) menjelaskan reaksi fisik yang dialami ketika individu merasa cemas, seperti tangan berkeringat, jantung berdebar, dan kaki gemetar. Situasi berbicara di depan umum dalam lingkup akademis adalah situasi yang paling ditakuti dan dihindari oleh seseorang yang mengalami fobia social tersebut. Pada situasi ini, siswa terlihat jarang berbicara atau jarang berani tampil berbicara di depan kelas, sehingga secara tidak sadar akan memengaruhi prestasi belajarnya.

Beberapa peneliti menggunakan teknik expressive writing therapy sebagai metode intervensi dalam penelitiannya. Secara umum expressive writing therapy bertujuan untuk meningkatkan pemahaman bagi diri sendiri maupun orang lain; meningkatkan kreatifitas, ekspresi diri dan harga diri; memperkuat kemampuan komunikasi dan interpersonal; mengekspresikan emosi yang berlebihan (katarsis) dan menurunkan ketegangan, serta meningkatkan kemampuan dalam mengatasi masalah dan fungsi adaptif individudan, expressive writing therapy membantu individu untuk memahami dirinya dengan lebih baik, dan menghadapi depresi, distress, kecemasan, adiksi, ketakutan terhadap penyakit, kehilangan dan perubahan dalam kehidupannya.

Penelitian ini bertujuan menguji tingkat kecemasan siswa saat berbicara di depan umum dan memaparkan upaya meminimalisasi kecemasan siswa saat berbicara di depan umum dengan metode expressive writing therapy therapy

Penelitian ini bermanfaat bagi siswa yang mengalami fobia social atau kecemasan berbicara saat di depan umum. Dengan menggunakan expressive writing therapy terlihat perbandingan antara tingkat kecemasan saat berbicara di depan umum sebelum expressive writing therapy dan sesudah expressive writing therapy. Ada 2 manfaat yaitu pertama bagi siswa, berbicara di depan 
umum harus diasah dan dimiliki siswa sejak dini, melatih mental agar berani berbicara dihadapan orang banyak, untuk mengetahui secara mendasar mengenai teknik-teknik yang berkaitan dengan berbicara di depan umum. Sehingga mampu mengoptimalkan teknik-teknik berbicara di depan umum dengan maksimal tanpa ragu-ragu. Kedua bagi guru yaitu untuk memperkaya media dalam pembelajaran keterampilan berbicara khususnya bercerita, dan dapat mengembangkan keterampilan guru Bahasa dan Sastra Indonesia khususnya dalam menerapkan pembelajaran keterampilan menceritakan tokoh idola. Pada dunia pendidikan, siswa dituntut untuk melakukan interaksi lingkungan sebagai pembicara maupun pendengar, baik di lingkungan sekolah, luar sekolah, dan saat proses belajar mengajar merupakan interaksi secara verbal maupun non-verbal yang terjadi. Rakhmat dalam (Wahyuni, 2015) mengungkapkan bahwa tidak ada individu yang mampu hidup normal tanpa adanya proses komunikasi atau berbicara dengan orang lain. Berbicara merupakan cara seseorang berkomunikasi dengan orang lain untuk menyampaikan sesuatu yang diinginkan. Komunikasi adalah cara manusia berinteraksi dengan manusia lain. Berkomunikasi dengan orang lain merupakan situasi yang hampir terjadi di seluruh proses kehidupan. Komunikasi menentukan kualitas kehidupan manusia, dan memiliki kemampuan berkomunikasi yang efektif sangatlah diperlukan, untuk menyam- paikan ide, gagasan dan pengetahuan kepada masyarakat. Kenyataan yang terjadi selama ini berbeda, kemampuan berkomunikasi kurang dimiliki oleh banyak mahasiswa, mereka masih takut bila mendapatkan kesempatan berkomunikasi tampil di depan umum (Wahyuni, 20I5). Kemampuan berbicara di depan umum sangat diperlukan oleh siswa guna meningkatkan kualitas diri. Berbicara di depan umum merupakan medium penting bagi pembentukan atau pengembangan pribadi dan untuk kontak sosial. Melalui komunikasi kita tumbuh dan belajar, kita menemukan pribadi kita dan orang lain, kita bergaul, bersahabat, bermusuhan, mencintai atau mengasihi orang lain, membenci orang lain, dan sebagainya (Fitriani \& Safithry, 20I8).

Menurut Tarigan dalam (Ririn et al., 2013) berbicara merupakan kemampuan untuk mengucapkan kata- kata, untuk megekspresikan, serta menyampaikan pikiran, gagasan dan perasaan.Kemampuan berbicara di depan umum akan mempermudah siswa menyampaikan ide dan gagasan mereka kepada publik. Kemampuan berbicara didapatkan dari hasil belajar, sebagaimana dikemukakan oleh Slameto dalam (Gutara et al., 2017) bahwa belajar adalah suatu proses usaha yang dilakukan seseorang untuk memperoleh suatu perubahan tingkah laku yang baru sebagai hasil pengalamannya sendiri dalam interaksi dengan lingkungannya. Tarigan dalam (Sudarminah, 2009) mengartikan berbicara adalah kemampuan mengucapkan bunyi-bunyi artikulasi atau kata-kata untuk mengekspresikan, menyatakan serta menyampaikan pikiran, gagasan dan perasaan. Siswa dituntut untuk berbicara, mengemukakan pendapat dan ide-idenya secara lisan di depan orang banyak (Purwati et al., 20I2). Adha dalam (Oktavianti \& Rusdi, 20I9) seni berbicara yang efektif dan berhasil dapat dipelajari dan dilatih oleh semua orang. Modal yang diperlukan adalah kerja keras serta teknik yang tepat. Terdapat empat indikator untuk mengetahui efektifitas berbicara yakni menghasilkan pengertian atau pemahaman, menghasilkan kepuasan atau hiburan, menghasilkan pengaruh pada sikap, dan menghasilkan hubungan yang lebih baik lagi.

Perasaan cemas pada saat mengawali berbicara di depan umum adalah hal yang hampir pasti dialami oleh semua orang. Bahkan seseorang yang telah berpengalaman berbicara di depan umum pun tidak terlepas dari perasaan ini. Menurut Atkinson dalam (Muslimin, 2013) menyatakan kecemasan adalah emosi yang tidak menyenangkan yang ditandai dengan istilah-istilah "kekhawatiran". "keprihatinan", "rasa takut", yang dialami dalam tingkat berbeda beda. Kecemasan adalah sesuatu yang menimpa hampir setiap orang pada waktu tertentu dalam kehidupannya. Kecemasan merupakan reaksi normal terhadap situasi yang sangat menekan kehidupan seseorang dan hal tersebut tidak berlangsung lama. Kecemasan akan berubah menjadi ancaman dan menciptakan ketegangan dan rasa tidak menyenangkan (Wahyuni, 2015). Nevid, Rathus, \& Greene dalam (Djayanti \& Rahmatika, 2015) mengungkapkan bahwa kecemasan merupakan suatu keadaan emosional atau keadaan khawatir akan sesuatu yang buruk segera terjadi. Kecemasan berbicara di depan publik tergolong pada kriteria fobia sosial maupun gangguan kecemasan social, kondisi tersebut ditandai dengan ketakutan dalam menunjukkan performansi maupun situasi 
interaksionalnya dengan orang lain (Haryanthi \& Tresniasari, 20I2). Kecemasan berbicara didepan umum merupakan perasaan cemas yang dirasakan oleh pembicara ketika melakukan presentasi di depan kelas yang muncul karena adanya pikiran negatif yang ditandai dengan munculnya gejala fisik dan psikologis serta perilaku menghindar (Fitri, 2017).

Menurut Maramis dalam (Julianto et al., 2018) memberikan pengertian bahwa kecemasan merupakan gejala-gejala komponen psikologik yang timbul akibat rasa was-was, khawatir akan terjadi sesuatu yang tidak menyenangkan. Kecemasan berbicara di depan umum merupakan suatu perasaan yang terancam, tidak menyenangkan, dan tertekan dengan diikuti oleh reaksi fisik dan psikis akibat kekhawatiran tidak mampu menyesuaikan atau menghadapi situasi pada saat berbicara di depan umum tanpa sebab khusus yang pasti, yang muncul sebelum atau selama berbicara di depan umum. Kecemasan juga berkaitan dengan perasaan tidak enak yang memiliki banyak penyebab seperti kesehatan individu, hubungan sosial, ketika hendak menjalankan ujian sekolah, masalah pekerjaan, hubungan internal dan lingkungan sekitar (Julianto et al., 2018). McCroskey, Richmond, Dali, \& Falcione dalam (Wibawanti et al., 2018) menyatakan bahwa individu yang memiliki kecemasan berbicara di depan umum memiliki kecenderungan yang lebih besar untuk khawatir, tidak efektif dalam berinteraksi dengan audiens, dan bahkan ada yang menarik diri dari individu lain.

Kecemasan berbicara di depan kelas dapat menjadi salah satu faktor penghambat belajar karena dapat mengganggu fungsi kognitif siswa. Jika siswa mengalami kecemasan berbicara di depan kelas, siswa sulit memahami materi yang disampaikan oleh guru, siswa tidak bisa percaya diri, kemampuan komunikasinya terhambat, tidak mau bertanya kepada guru dan lain-lain. Kecemasan yang dialami oleh siswa juga dapat berimbas pada pencapaian hasil belajar yang tidak maksimal. Semakin sering siswa mengalami kecemasan berbicara di depan kelas maka semakin sulit ia memahami materi yang disampaikan oleh guru dan semakin tidak percaya diri ketika berbicara di depan kelas, hal ini akan menghambat hasil belajar yang tidak maksimal dan menghambat siswa dalam mengembangkan potensi, minat dan bakat yang ia miliki (Argarini et al., 2019). Kecemasan suatu keadaan psikologis dimana individu terus menerus dalam keadaan khawatir yang kurang jelas dan menyakitkan ketika mengemukakan pendapat aspek dari diantaranya aspek fisiologis yang meliputi detak jantung cepat, nafas sesak, keringat bercucuran, sebentar- sebentar ingin buang air kecil, muka pucat, badan gemetaran, tidak berani menatap lawan bicara/menundukan kepala, kepala pusing, badan terasa lemas. Kedua Aspek psikologis meliputi tidak percaya diri, tidak konsentrasi, tidak mampu mengembangkan kualitas diri, tidak memiliki pertimbangan dan pengarahan yang rasional, tegang, cemas, frustasi, lari dari kenyataan (Istiqomah \& Habsy, 2019).

Menurut Monarth \& Kase dalam (Haryanthi \& Tresniasari, 20I2) faktor-faktor yang memengaruhi individu mengalami kecemasan berbicara di depan publik, pertama faktor biologis, rasa takut maupun cemas dialami semua orang ketika berhadapan dengan bahaya. Pada saat menghadapi situasi yang membuatnya merasa tidak nyaman, respon fisiologis yang tampak adalah, pertama, sistem saraf simpatis memproduksi \& melepaskan adrenalin yaitu suatu hormon fight (Menghadapi ) dan flight (Menghindari) situasi bahaya. Kedua, detak jantung berdebar dengan kuat; tekanan darah naik; wajah bersemu merah. Ketiga, merasakan adanya sensasi dingin dan gemetar pada tangan dan kaki. Keempat, nafas memburu dengan cepat; sulit mengatur pernafasan dan mengalami sakit kepala ringan. Kelima, berkeringat pada sekujur tubuh. Kedua faktor pikiran negative, pikiran akan memicu respon biologis sebaliknya adakalanya respon biologis yang menampakkan kecemasan dan pikiran negatif akan menyertainya. Pikiran negatif yang umumnya timbul bahwa berbicara di depan umum menakutkan. Pikiran yang terlalu berlebihan terhadap konsekuensi negatif dari suatu situasi sosial. Penalaran emosi merupakan suatu pemikiran tentang adanya perasaan cemas misalnya sakit perut akan menyebabkan individu mengungkapkan pendapat dengan buruk. Adanya perasaan kurang mampu mengatasi beberapa kesulitan pada situasi sosial. Fokus terhadap aspek negatif dari suatu situasi dan mengabaikan hal-hal yang positif. Ketiga faktor perilaku menghindar, kita ingin menghindari situasi yang membuat tegang tersebut secepat mungkin dan tidak ingin kembali pada situasi yang sama. Ada beberapa perilaku yang muncul terkait dengan kondisi tersebut, yaitu menghindari situasi yang menakutkan. Respon yang tampak cenderung defensif maupun agresif pada situasi yang lain ada respon rasionalisasi untuk menghindar dengan membuat beberapa alasan; 
Perilaku cemas yaitu perilaku yang sering tampak dalam situasi berbicara di depan publik, sering kali dilakukan tanpa disadari bahwa individu sedang merasa cemas seperti tangan di saku, memainkan pulpen, meremas tangan, menyentuh dan memperbaiki tata letak rambut, berbicara cepat, berjalan mondar-mandir, gelisah dan lain-lain; Perilaku dengan kompensasi yang berlebihan. Perilaku tersebut muncul karena individu tersebut berupaya untuk meminimalkan aspek yang menakutkan pada situasi tersebut. Individu berupaya untuk mengontrol kecemasan, menutupi kecemasan atau gejala fisiologis dari orang lain misalnya menyembunyikan tangan yang gemetar, berbicara sedikit saat malu, mengulang-ulang pembicaraan. Perilaku tersebut secara langsung, berpengaruh terhadap performansi individu. Misalnya menghafal apa yang akan diungkapkan akan membuat tidak alamiah, mengulang isi pembicaraan akan memperlambat proses berkomunikasi. Keempat faktor emosional, saat kita menunjukkan situasi takut, kita mengalami respon fisiologis, kognitif dan perilaku yang menggambarkan situasi tersebut sehingga kita sendiri yang mengembangkan rasa takut tehadap situasi tertentu. Individu tersebut cenderung merasakan perasaan cemas, takut, kuatir, merasa tidak mudah menghadapi situasi sosial, tegang, panik, dan gugup menghadapi situasi berbicara di depan umum. Saat individu menghindari situasi berbicara di depan publik tersebut, mereka menyadari implikasinya terhadap karir dan kehidupan sosial. Hal tersebut menyebabkan perasaan depresi, murung, frustrasi, putus asa, dan perasaan takut.

Expressive writing therapy merupakan salah satu intervensi yang digunakan untuk mengatasi kecemasan. Melalui expressive writing therapy individu merefleksikan pikiran dan perasaan terdalamnya terhadap peristiwa yang tidak menyenangkan atau menimbulkan trauma. Refleksi ini memfasilitasi siswa untuk merubah kognitifnya, meregulasi emosi menjadi lebih baik, menjadi sarana katarsis, memperoleh energi baru, mengarahkan perhatian, meredakan tekanan emosional, serta memberi kesempatan untuk fokus pada tujuan dan perilakunya. Perubahan ini akan membuat masalah individu lebih mudah diatasi dan membebaskan individu dari tekanan mental yang senantiasa melingkupinya (Susanti \& Supriyantini, 2013). Menulis berbeda dengan berbicara. Menulis ekspresif memiliki suatu kekuatan tersendiri karena menulis adalah suatu bentuk eksplorasi dan ekspresi area pemikiran, emosi dan spiritual yang dapat dijadikan sebagai suatu sarana untuk berkomunikasi dengan diri sendiri dan mengembangkan suatu pemikiran serta kesadaran akan suatu peristiwa. Terapi menulis juga mencerminkan refleksi dan ekspresi subjek karena inisiatif sendiri atau sugesti dari seorang terapis (Rohmadani, 2017). Menulis ekspresif ini pada dasarnya sama-sama memakai media buku, jurnal atau buku diary pribadi dan blog, beberapa penelitian berbeda dalam penggunaan durasi menulis, karena setiap kasus memiliki tingkat kedalaman masalah yang berbeda, sehingga dibutuhkan cara dan durasi yang berbeda, untuk proses terapi kurang lebih dibutuhkan waktu 10-30 menit dalam proses menulis ekspresif. Menurut teori awalnya subjek diminta untuk masuk ke dalam ruangan dan diminta untuk menulis tentang bagaimana subjek menggunakan waktunya sehari-hari hingga pengalaman dalam kehidupannya, tentang perasaan-perasaannya kepada orang-orang disekitarnya, tentang masa lalu, masa sekarang dan impiannya,hingga konflik pribadinya (Rahmawati, 20I4).

Expressive writing therapy merupakan terapi yang menggunakan aktivitas menulis sebagai sarana untuk merefleksikan pikiran dan perasaan terdalam terhadap peristiwa yang tidak menyenangkan (menimbulkan trauma). Expressive writing therapy dapat digunakan sebagai terapi utama atau juga dapat diintegrasikan dengan pendekatan psikoterapi atau konseling lainnya, serta dilakukan secara individual dan kelompok. Pada penelitian ini expressive writing therapy dilakukan secara berkelompok dan merupakan terapi utama untuk membantu subjek mengembangkan insight yang lebih adekuat tentang diri dan situasi (Susanti dan Supriyantini, 20I3). Didalam teknik expressive writing ini banyak terdapat keterampilan yang dapat menunjang proses konseling khususnya untuk siswa yang sulit mengungkapkan pikiran atau perasaannya melalui bercerita atau berbicara dengan konselor Teknik expressive writing termasuk bagian dari terapi ekspresif yang berfokus pada emosi (Anggraini et al., 2019). Menurut Wright dalam (Susilowati \& Hasanat, 2015) expressive writing adalah suatu aktivitas menulis yang mencerminkan refleksi dan ekspresi klien baik itu karena inisiatif sendiri atau sugesti dari seorang terapis atau peneliti. Beberapa peneliti menggunakan teknik expressive writing sebagai metode intervensi dalam penelitiannya, seperti yang dilakukan oleh 
Klein dan Adriel dalam (Rahmawati, 2014) juga meneliti tentang expressive writing yang hasilnya dibahas dalam kerangka model yang didasarkan pada kognitif dan teori psikologi sosial dimana penulisan ekspresif mengurangi untuk berpikir tentang pengalaman stres, sehingga membebaskan sumber informasi working memory. Paez dalam (Qonitatin et al., 20ll) mencatat bahwa menghadapi atau berkonfrontasi dengan peristiwa-peristiwa penuh tekanan dan traumatis yang dilakukan dalam prosedur expressive writing dilaporkan menghasilkan tingkat yang lebih tinggi dalam kesehatan fisik (misalnya, lebih sedikit mengunjungi fasilitas kesehatan).

\section{Metode}

Penelitian tentang upaya meminimalisasi kecemasan siswa saat berbicara di depan umum dengan metode expressive writing therapy merupakan penelitian tindakan kelas. Penelitian ini dimaksudkan untuk memaparkan tingkat kecemasan siswa saat berbicara di depan umum dan memaparkan upaya meminimalisasi kecemasan siswa saat berbicara di depan umum dengan metode expressive writing therapy bagi siswa SMP N I Gatak kelas VIIC. Penelitian ini dilakukan di SMP N I Gatak bagi siswa yang bertempatkan di kelas VIIC tahun ajaran 2019/2020. Waktu penelitian ini dilakukan pada 7 November 2019, beserta pelaksanaan praktik berbicara di depan kelas setelah itu pembagian instrumen penelitian (Angket). Pada tanggal 13 November 2019 melakukan metode expressive writing therapy pelaksanaan praktik siswa kedepan kelas untuk kedua kalinya. Penelitian ini dilakukan selama $2 \times 45$ menit atau 2 jam mata pelajaran. Untuk Pertemuan kedua diberi waktu selama 3 jam mata pelajaran. Subjek pada penelitian ini adalah siswa kelas VIIC SMP N I Gatak, tahun ajaran 2019/2020. Jumlah siswa kelas VIIC yaitu 32 siswa. Terdiri dari 12 siswa laki-laki dan 20 siswa perempuan. Instrument penelitian ini menggunakan angket, angket diberikan kepada siswa yang mengalami kecemasan saat berbicara di depan umum. Sehingga sumber data yang di dapatkan berupa hasil angket siswa yang mengalami kecemasan saat berbicara di depan umum. Validitas data diuji kepada 32 siswa VIIC yang sudah melakukan praktik berbicara di depan kelas. Jumlah poin instrument penelitian (angket) sebanyak 24 pertanyaan. Setelah dilakukan perhitungan validitas data dari angket terdapat 10 siswa yang mengalami kecemasan berbicara di depan umum dengan tingkat yang sangat tinggi. Hasil dari perhitungan validitas data instrumen penelitian (angket) mengenai kecemasan berbicara di depan umum, terdiri dari tingkatan rendah, sedang, tinggi, sangat tinggi. Hasil angket ini dilakukan sebelum dilakukan metode expressive writing therapy. Pada proses pengumpulan data peneliti menggunakan angket atau kuesioner. Angket bertujuan untuk mengukur tingkat kecemasan berbicara di depan umum siswa. Dimana dalam satu pertemuan terlebih dahulu praktik lalu dilakukan pemberian angket atau kuesioner tingkat kecemasan kepada siswa sehingga di dapatkan hasil tingkat kecemasan sebelum dilakukannya metode expressive writing therapy. Kemudian dipertemuan ke dua siswa menerapkan metode expressive writing therapy lalu praktik setelah itu di berikan kembali angket tingkat kecemasan berbicara di depan umum untuk melihat perubahan setelah di berikan metode expressive writing therapy. Analisis data dalam penelitian ini, yaitu berupa editing, scoring dan tabulating. Editing, setelah angket pertama dan ke dua diisi oleh siswa, selanjutnya peneliti melakukan pengecekan kembali angket yang telah diisi oleh siswa apakah sudah lengkap dan tidak ada yang kosong, apabila ada angket yang belum terjawab, maka peneliti memberikan kembali pada siswa untuk di isi. Scoring Berfungsi untuk menghitung jumlah siswa yang mengalami kecemasan saat berbicara di depan umum berdasarkan jawaban atas pertanyaan yang ada diangket. Tabulating digunakan untuk memasukkan hasil perhitungan ke dalam bentuk tabel dan melihat persentase dari jawaban pengolahan data.

Penelitian ini melakukan uji expressive writing therapy pertama dan uji expressive writing therapy kedua. Pada uji expressive writing therapy pertama, siswa melakukan praktik keterampilan berbicara di depan kelas meliputi bercerita, berpidato, atau ceramah. Setelah melakukan praktik, siswa mengisi angket yang telah diberikan lalu Angket dikumpulkan secara kolektif. Pada uji expressive writing therapy kedua yaitu pelaksanaan expressive writing therapy, siswa menulis tentang apa yang akan diungkapkan baik itu bercerita, berpidato atau berceramah. Setelah itu siswa melakukan praktik ke depan kelas mengenai hasil expressive writing therapy yang telah ia tulis dengan urutan pelaksanaan praktik di depan kelas sesuai hasil angket pertama yang memiliki tingkat kecemasan 
yang sangat tinggi. Setelah melakukan praktik, siswa mengisi angket yang diberikan. Lalu Angket dikumpulkan secara kolektif.

\section{Hasil}

Hasil pengamatan berdasarkan siklus pertama yaitu 6 siswa mengalami kecemasan berbicara di depan umum dengan tingkatan sedang. 16 siswa mengalami kecemasan berbicara di depan umum dengan tingkatan tinggi. 10 siswa mengalami kecemasan berbicara di depan umum dengan tingkatan sangat tinggi. Setelah editing lalu melakukan scoring untuk menghitung jumlah siswa yang mengalami kecemasan saat berbicara di depan umum berdasarkan jawaban atas pertanyaan yang ada diangket. Dalam penelitian ini untuk memberi skor siswa yang memiliki kecemasan berbicara di depan umum hasil jawaban angket diambil dari siswa yang memiliki jawaban selalu/sering yaitu I siswa yg menjawab 5 pertanyaan dengan jawaban selalu/sering tidak ada, termasuk tingkatan rendah. I siswa yang menjawab 7 pertanyaan dengan jawaban selalu/sering berjumlah 6 siswa, termasuk tingkatan sedang. I siswa yang menjawab 10 pertanyaan dengan jawaban selalu/sering berjumlah 16 siswa, termasuk tingkatan tinggi. I siswa yang menjawab 20 pertanyaan dengan jawaban selalu/sering berjumlah 10 siswa, termasuk tingkatan sangat tinggi. Angket berisi 24 pertanyaan, setiap pertanyaan memiliki poin 4,16. Maka jika siswa menjawab 7 pertanyaan dengan jawaban selalu/sering mendapatkan skor 29,12. Jika siswa menjawab 10 soal dengan jawaban selalu/sering mendapatkan $4 \mathrm{I}$,6. Jika siswa menjawab 20 pertanyaan dengan jawaban selalu/sering mendapatkan skor 83,2.

Nilai rata-rata 32 siswa pada siklus I mencapai 52,26. Berdasarkan data di atas $f$ adalah jumlah siswa yang mengalami kecemasan berbicara di depan umum, $x$ adalah skor jawaban siswa yang menjawab angket sesuai tingkatan sedang, tinggi, dan sangat tinggi dan $f . x$ adalah hasil dari jumlah siswa yang mengalami kecemasan berbicara di depan umum dengan skor jawaban siswa yang angket sesuai tingkatan sedang, tinggi, dan sangat tinggi. Total nilai 6 siswa yang memiliki kecemasan berbicara di depan umum dengan tingkatan sedang adalah 174,72. Total nilai 16 siswa yang memiliki kecemasan berbicara di depan umum dengan tingkatan tinggi adalah 665,6 dan nilai I0 siswa yang memiliki kecemasan berbicara di depan umum dengan tingkatan sangat tinggi adalah 832.

Hasil pengamatan berdasarkan siklus kedua yaitu I siswa mengalami kecemasan berbicara di depan umum dengan tingkatan sedang. 5 siswa mengalami kecemasan berbicara di depan umum dengan tingkatan tinggi. 2 siswa mengalami kecemasan berbicara di depan umum dengan tingkatan sangat tinggi. Nilai rata-rata 32 siswa pada siklus II mencapai 50,44. Total nilai I siswa yang memiliki kecemasan berbicara di depan umum dengan tingkatan sedang adalah 29,12. Total nilai 5 siswa yang memiliki kecemasan berbicara di depan umum dengan tingkatan tinggi adalah 208 dan nilai 2 siswa yang memiliki kecemasan berbicara di depan umum dengan tingkatan sangat tinggi adalah 166,4. Rata-rata nilai menjadi 50,44. Hasil pengamatan siklus II tingkat kecemasan berbicara di depan umum berkurang setelah melakukan metode expressive writing therapy. Siswa yang awalnya mengalami gemetar, gugup, tegang, berbicara menjadi terbata-bata, jantung berdebar lebih cepat, berkeringat, tangan terasa dingin, nafas lebih cepat, pikiran tidak karuan dan kurang konsentrasi, setelah melakukan metode expressive writting therapy siswa yang mengalami kecemasan berbicara berkurang.

Berdasarkan deskripsi hasil siklus pertama, siswa dituntut melakukan praktik berbicara di depan kelas setelah itu mengisi angket. Sedangkan deskripsi hasil siklus kedua, siswa menerapkan metode expressive writting therapy. Lalu melakukan praktik berbicara di depan kelas dari hasil expressive writing atau menulis ekspresif yang telah dibuat siswa. setelah itu siswa mengisi angket kedua. Dalam hasil pengamatan siklus pertama berdasarkan hasil angket yaitu 6 siswa mengalami kecemasan berbicara di depan umum dengan tingkatan sedang, 16 siswa siswa mengalami kecemasan berbicara di depan umum dengan tingkatan tinggi, dan 10 siswa siswa mengalami 
kecemasan berbicara di depan umum dengan tingkatan sangat tinggi. Hasil pengamatan siklus kedua, tingkat kecemasan berbicara di depan umum berkurang setelah melakukan metode expressive writing therapy. Dengan hasil siswa mengalami kecemasan berbicara di depan umum dengan tingkatan sangat tinggi berkurang dari 10 siswa menjadi 2 siswa, siswa mengalami kecemasan berbicara di depan umum dengan tingkatan tinggi berkurang dari 16 siswa menjadi 5 siswa, siswa mengalami kecemasan berbicara di depan umum dengan tingkatan sedang berkurang dari 6 siswa menjadi I siswa.

Berdasarkan hasil pengamatan siklus pertama dengan siklus kedua menunjukkan bahwa siswa yang mengalami kecemasan berbicara di depan umum berjumlah 32 dengan rata-rata nilai 52,26. Terdapat perbedaan tingkat kecemasan berbicara di muka umum setelah melakukan expressive writing therapy, dengan hasil siswa yang mengalami kecemasan berbicara di depan umum berjumlah 8 siswa dengan rata-rata nilai 50,44. Metode ini memiliki keunggulan untuk mengatasi berbagai masalah termasuk kecemasan. Keunggulan tersebut diantaranya adalah bahwa melalui proses menulis dapat memberi jalan bagi munculnya ingatan, perasaan, dan pikiran di pendam; membantu mengorganisasikan pikiran, ide-ide, dan inspirasi yang dimiliki individu; prosesnya bersifat holistik yang memberikan kesadaran mental melalui proses eksplorasi pengalaman. Keunggulan tersebut tebukti dari hasil perbedaan siklus I dengan siklus II menunjukkan bahwa 24 siswa berhasil melakukan metode expressive writing therapy dengan selisih rata-rata I,82. Jadi penurunan kecemasan berbicara di depan umum setelah melakukan metode expressive writing therapy sebesar $3,5 \%$.

\section{Pembahasan}

Penelitian ini dilakukan pada dua kali uji coba, uji coba pertama, siswa melakukan pratik keterampilan berbicara di depan kelas meliputi bercerita, berpidato, atau ceramah. Setelah melakukan praktik, siswa mengisi angket yang telah diberikan. Angket dikumpulkan secara kolektif. Uji Coba kedua, pelaksanaan expressive writing therapy, siswa menulis ekspresif tentang apa yang akan diungkapkan baik itu bercerita, berpidato atau berceramah. Siswa melakukan praktik di depan kelas mengenai hasil expressive writing yang telah ia tulis. Urutan pelaksanaan praktik ke depan kelas sesuai hasil angket pertama yang memiliki tingkat kecemasan yang sangat tinggi. Setelah melakukan praktik, siswa mengisi angket yang telah diberikan. Angket dikumpulkan secara kolektif. Perubahan kecemasan berbicara di depan umum akan terlihat sebelum dan sesudah expressive writing therapy.

Teknik menulis ekspresif ini pada dasarnya sama-sama memakai media buku, jurnal atau buku diary pribadi dan blog. Beberapa penelitian berbeda dalam penggunaan durasi menulis, karena setiap kasus memiliki tingkat kedalaman masalah yang berbeda, sehingga dibutuhkan cara dan durasi yang berbeda. Untuk proses terapi kurang lebih dibutuhkan waktu 10-30 menit dalam proses menulis ekspresif. Menurut teori awalnya subjek diminta untuk masuk ke dalam ruangan dan diminta untuk menulis tentang bagaimana subjek menggunakan waktunya sehari-hari hingga pengalaman dalam kehidupannya, tentang perasaan-perasaannya kepada orang-orang disekitarnya, tentang masa lalu, masa sekarang dan impiannya,hingga konflik pribadinya (Rahmawati, 20I4). Dalam penelitian ini siswa menulis ekspresif dengan memakai media buku.

\section{Kesimpulan}

Berdasarkan hasil paparan penelitian yang telah dilakukan dapat ditarik kesimpulan sebagai berikut : Berdasarkan hasil angket pertama yaitu 6 siswa mengalami kecemasan berbicara di depan umum dengan tingkatan sedang. 16 siswa mengalami kecemasan berbicara di depan umum dengan tingkatan tinggi. 10 siswa mengalami kecemasan berbicara di depan umum dengan tingkatan sangat tinggi. Dalam hasil pengamatan, kecemasan siswa saat berbicara di depan kelas paling dominan mengalami gemetar, gugup, tegang, berbicara menjadi terbata-bata, jantung berdebar lebih cepat, berkeringat, tangan terasa dingin, nafas lebih cepat, pikiran tidak karuan dan kurang konsentrasi. Jadi total siswa yang mengalami kecemasan berbicara di depan umum berjumlah 32 siswa. 
Hasil setelah melakukan expressive writing therapy tingkat kecemasan berbicara di depan umum berkurang setelah melakukan metode expressive writing therapy. Dengan hasil siswa mengalami kecemasan berbicara di depan umum dengan tingkatan sangat tinggi berkurang dari 10 siswa menjadi 2 siswa, siswa mengalami kecemasan berbicara di depan umum dengan tingkatan tinggi berkurang dari 16 siswa menjadi 5 siswa, siswa mengalami kecemasan berbicara di depan umum dengan tingkatan sedang berkurang dari 6 siswa menjadi I siswa. Hasil uji expressive writing therapy efektif untuk siswa, karena memiliki keunggulan untuk mengatasi berbagai masalah termasuk kecemasan berbicara di depan umum. Keunggulan tersebut diantaranya adalah bahwa melalui proses menulis ekspresif dapat memberi jalan bagi munculnya ingatan, perasaan dan pikiran yang di tekan atau dipendam; membantu mengorganisasikan pikiran, ide-ide dan inspirasi yang dimiliki siswa. Keunggulan tersebut tebukti dari hasil pengamatan dan hasil angket bahwa 24 siswa berhasil melakukan metode expressive writing therapy yang awalnya 32 siswa mengalami kecemasan di depan umum.

\section{REFERENSI}

Anggraini, S., Hitipeuw, I., \& Mappiare, A. (2019). Keefektifan Teknik Expressive Writting untuk Mereduksi Emosi Negatif Siswa SMA. Jurnal Pendidikan, 4(I), 36-39.

Argarini, V., Gani, S., \& Putri, R. M. (2019). Pengaruh Bimbingan Kelompok Dengan Teknik Sosiodrama Dalam Mengurangi Kecemasan Berbicara Di Depan Kelas Pada Siswa Kelas VII Di SMP Negeri 10 Palembang. Jurnal Konsling Komprehensif, 6(I), I-I0.

Bukhori, B. (20I6). Kecemasan Berbicara di Depan Umum Ditinjau dari Kepercayaan Diri dan Keaktifan Dalam Organisasi Kemahasiswaan. Jurnal Komunikasi Islam, 6(I), I58-I86. https://doi.org/I0.I5642/JKI.2016.6.I.I58-I86

Cahyawan, W., \& Machdum, S. V. (2019). Dukungan Sosial Bagi Perempuan Pra-Sejahtera Melalui Program Keuangan Mikro: Studi Kasus Pada Koperasi Mitra Dhuafa Cabang Cikalongkulon. Jurnal Psikologi Ulayat, 6(2), I75-20 I. https://doi.org/I0.24854/jpu020 I9-253

Djayanti, W., \& Rahmatika, R. (20I5). Hubungan Antara Efikasi Diri Dengan Kecemasan Berbicara Di Depan Umum Pada Mahasiswi. Jurnal Psikogenesis, 3(2), 187-198.

Fitri, D. (2017). Efektivitas Cognitive Behavior Therapy Untuk Mahasiwa Cognitive Behavior Theraphy Effectiveness in Reducing Students Public Speaking Anxiousness. Jurnal Psikologi, 10(I), 64-73.

Fitriani, \& Safithry, E. A. (2018). Efektivitas Layanan Konseling Individual Pendekatan Rebt Untuk Mengunrangi Kecemasan Berbicara Di Depan Umum Pada Peserta Didik di SMA Negeri 2 Palangkaraya. Jurnal Bimbingan Dan Konseling, 3(2), 22-25. https://doi.org// 0.33084/suluh.v3i2.502

Gutara, M. Y., Rangka, I. B., \& Prasetyaningtyas, W. E. (20I7). Layanan Penguasaan Konten untuk Meningkatkan Keterampilan Berbicara di Depan Umum Bagi Siswa. Jurnal Fokus Konseling, 3(2), 138-I47. https://doi.org// 0.26638/jfk.407.2099

Haryanthi, L. P. S., \& Tresniasari, N. (20I2). Efektivitas Metode Terapi Ego State dalam Mengatasi Kecemasan Berbicara di Depan Publik pada Mahasiswa Fakultas Psikologi UIN Syarif Hidayatullah Jakarta. Jurnal Insan, 14(5), 32-40.

Istiqomah, D., \& Habsy, B. A. (2019). Keefektifan Konseling Realita untuk Mengatasi Kecemasan Mengemukakan Pendapat pada Siswa SMP. Indonesian Journal of Educational Counseling, 3(I), 6I-70. https://doi.org//0.30653/00I.201931.48

Julianto, V., Indriyani, R., \& Munir, M. M. (2018). Pengaruh Membaca Al Fatihah Reflektif Intuitif terhadap Penurunan Tingkat Kecemasan Berbicara di Depan Umum pada Mahasiswa Prodi Psikologi UIN Sunan Kalijaga Yogyakarta. Jurnal Psikologi, I3(2), I62-I7I. https://doi.org//0.240I4/jp.v I3i2.4299

Muslimin, K. (2013). Faktor - Faktor yang Memengaruhi Kecemasan Berrkomunikasi di Depan Umum (Kasus Mahasiswa Fakultas Dakwah INISNU Jepara). Jurnal Interaksi, 2(2), I45-I55. https://doi.org/I0.147I0/interaksi.2.2.145-I55

Oktavianti, R., \& Rusdi, F. (2019). Belajar Public Speaking Sebagai Komunikasi yang Efektif. Jurnal Bakti Masyarakat Indonesia, 2(I), II7-122. 
Purwati, S., Sugiyono, \& Tajri, I. (20I2). Model Bimbingan Kelompok Dengan Teknik Fun Game Untuk Mengurangi Kecemasan Berbicara Didepan Kelas. Jurnal Bimbingan Konseling, I(I), 8287.

Qonitatin, N., Widyawati, S., \& Asih, G. Y. (20II). Pengaruh Katarsis Dalam Menulis Ekspresif Sebagai Intervensi Depresi Ringan Pada Mahasiswa. Jurnal Psikologi Undip, 9(I), 2 I-32.

Rahmawati, M. (20I4). Menulis Ekspresif Sebagai Strategi Mereduksi Stres Untuk Anak-Anak Korban Kekerasan Dalam Rumah Tangga (Kdrt). Jurnal Ilmiah Psikologi Terapan, 02(02), 276293.

Ririn, Asmidir, \& Marjohan. (2013). Hubungan Antara Keterampilan Komunikasi Dengan Kecemasan Berbicara Di Depan Umum. Jurnal Imiah Konsling, 2(I), 273-278. https://doi.org//0.24036/0201321 I 203-0-00

Rohmadani, Z. V. (2017). Relaksasi Dan Terapi Menulis Ekspresif Sebagai Penanganan Kecemasan Pada Difabel Daksa. Journal of Health Studies, I (I), I8-27.

Saputri, V., \& Indrawati, E. S. (2017). Hubungan Antara Konsep Diri Dan Kecemasan Berbicara Di Depan Umum Pada Siswa Kelas Xi Sma Negeri 3 Sukoharjo. Jurnal Empati, 6(I), 425-430.

Sudarminah, S. (2009). Upaya Peningkatan Pembelajaran Berbicara dengan Model Pembelajaran Gambar Seri untuk Siswa Kelas VIII SMP Negeri 6 Semarang. Lemlit, 3(2), 45-52.

Susanti, R., \& Supriyantini, S. (20I3). Pengaruh Expressive Writing Therapy Terhadap Penurunan Tingkat Kecemasan Berbicara Di Muka Umum Pada Mahasiswa. Jurnal Psikologi, 9(2), I19129.

Susilowati, T. G., \& Hasanat, N. U. (2015). Pengaruh Terapi Menulis Pengalaman Emosional Terhadap Penurunan Depresi Pada Mahasiswa Tahun Pertama. Jurnal Psikologi, 38(I), 92-107. https://doi.org// 0.22I 46/jpsi.7669

Wahyuni, E. (2015). Hubungan Self-Effecacy dan Keterampilan Komunikasi dengan Kecemasan Berbicara di Depan Umum. Jurnal Komunikasi Islam, 05(0I), 52-82.

Wibawanti, I. P., Sari, E. P., \& Puspa, V. (2018). Pelatihan Mengatasi Kecemasan Berbicara Di Depan Umum Pada Kader Kesehatan Jiwa. Jurnal Pengabdian Masyarakat, 2(3), 109-II 1. 